\title{
From Content to Context: Understanding Introduction to Sociology Through MOOC
}

\author{
https://doi.org/10.3991/ijet.v15i07.13467 \\ Luhung Achmad Perguna, Idris ${ }^{(\bowtie)}$, Irawan \\ Universitas Negeri Malang, Malang, Indonesia \\ idris.fis@um.ac.id
}

\begin{abstract}
This study aims to provide interactive, active participatory and collaborative media for learners through MOOC in the Introduction to Sociology course. This paper presents alternative learning by utilizing MOOC-based information technology as one way to achieve learning objectives. This development uses research and development (R\&D) with development steps consisting of preproduction, production, and postproduction. This development was also validated and implemented during the development process. This study found that development products are feasible to be implemented as learning products. In addition, the results of the implementation test also showed that the use of MOOC media through the development of context-based video learning can improve student understanding more easily, more effectively, and more efficiently. Thus, this development product can be one of the learning media that can be used in the sociology learning process.
\end{abstract}

Keywords-MOOC; Video; Content; Context; Introduction of Sociology.

\section{Introduction}

Advances in information technology in the last few decades have significantly changed the way of life, work, and human learning [1]-[4]. In addition, the development of information and technology in the world also dramatically positions education in the midst of the Internet of Thing age [5] which provides the broadest opportunity for anyone to be able to access it [6]. The internet of things which is also one of the products of the fourth industrial revolution has transformed great changes or the great transformation) through digitalization in all aspects of life [7], [8]. The Industrial Revolution 4.0 has also created new technologies in data science, artificial intelligence, robotics, cloud, three-dimensional printing, and nanotechnology, which have disrupted previous innovations.

The old paradigm of learning in class slowly and surely began to be replaced by the presence of online learning media [9]. In other words, the use of information technology media in education is a demand that cannot be ignored by educators. As part of the internet of things era, learning with the Massive Open Online Course (MOOC) model is a medium that provides great opportunities [10] in the quality of learning and teaching [9], [11]. Through MOOC, every material provided can be accessed easily without time and space. In addition, learning can also be arranged with a variety of learning 
activities that are varied and rich with quality learning material [9], [12], [13]. Therefore, the effort to develop learning not only requires material substance, but also innovative creation in learning. Innovative creative work in learning needs to be encourage to the development and strengthening of $\mathrm{MOOC}$ as one of the future learning models [14]. MOOC is an online class that allows anyone to be active anywhere through video lectures, computerized grading evaluations, and discussion forums [15].

The development of MOOC, especially in the introduction to sociology, has become important as a foundation in introducing sociology to the public, both high school students, college students, and also people who want to have sociological imagination (C. Wright Mills) or become peeping toms (social peers) ( Peter L Berger). The just in case principle (which is centered on a particular case) in traditional learning, through MOOC, can be a just in time service which means that the public can access this service anytime and anywhere, in contrast to conventional learning that is bound by time and location. At the same time, MOOC's invites active public participation through the lesson learner feature. In turn, it will shape lifelong networking learning through active and participatory collaboration. The evaluation presented at the end of the video show in MOOC serves as a measure of achievement of learning objectives including measuring the level of learning progress. MOOC is more about context even without nullifying content. A content is still at the core, but learning does not occur in a vacuum so that it occurs in the context of massive interactions with other learners.

MOOC as a course through online mode is still not much developed as a massive learning product in regular lectures at Higher Education institutions. MOOC sites that have been developed in Indonesia are still very limited, such as IndonesiaX, FOCUS, UCEO, and others. These sites have many unique visitors as well as containers for a variety of well-known institutions in Indonesia. The nature of this product that is open to the public is very likely to be accessed for anyone who wants to learn Sociology quickly, precisely, cheaply and superbly. Thus, the aim of this development is to provide an interactive, participatory and collaborative media for learners through MOOC in the Introduction to Sociology course.

\section{Method}

This development uses research and development (R\&D) with development steps consisting of preproduction, production, and postproduction as follows: 


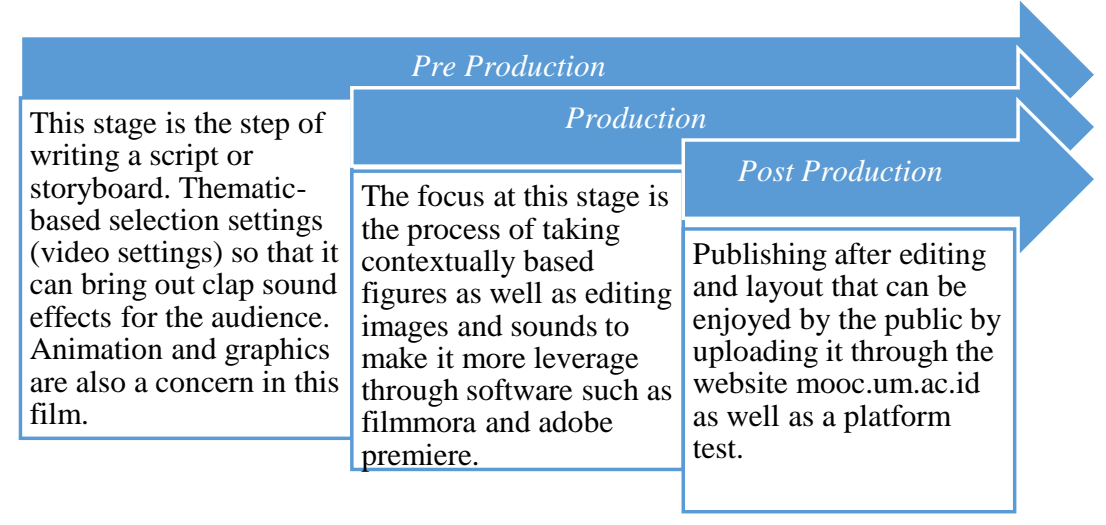

Fig. 1. The steps of development

\subsection{Pre-production}

Good planning is the beginning of success. Learning Innovation with this MOOC platform is planned carefully. The Semester Learning Plan is the key in making MOOC so that it has a real impact after being developed. The material involved is 5 out of 14 materials available in the course plan. The innovation development team agreed on five materials based on the urgency of the material for both students and audiences who wanted to join the MOOC as follows:

a) Understanding Sociology

b) Social Interaction and Social Structure

c) Social transformation

d) Local culture and global culture

e) Gaps, stratification and mobility

Determining the five materials as content and writing a script or story board becomes another important part that must be compiled. Story board writing is compiled with the development team through a brainstorming process to obtain relevant and supportive results in learning activities.

One of the differences between the development of this learning innovation with other platforms is the determination of the video background. MOOC displayed in the courses seem monotonous and always focused on the speaker. In developing this innovation, the selection of settings and video settings is very important. The thematic-based setting (video background) is determined to bring out the clap sound effect to the audience. This will foster deeper understanding. Other important aspects at this stage of production are animation, music and graphics. 


\subsection{Production}

This process focuses on contextual based image capture that is tailored to the story board that has been created to be able to produce a significant impact especially in producing clap sound effects. This means that the audience will be brought to build sociological imagination through videos that are aired and can focus on what is conveyed. It aims to eliminate boredom for users or audiences to view and watch videos.

\subsection{Post production}

Post production is a stage where the MOOC platform is tested its usefulness for the audience by implementing it to the 2018 class of sociology education students at Malang State University who took the Introduction to Sociology. The next process is editing, lay outing, and publishing products for the public through the website.

Table 1. Setting for MOOC Platform

\begin{tabular}{|l|l|}
\hline \multicolumn{1}{|c|}{ Materials } & \multicolumn{1}{c|}{ Setting } \\
\hline Understanding Sociology & $\begin{array}{l}\text { Slamet Garden } \\
\text { Coffee shop in Malang City } \\
\text { Universitas Negeri Malang } \\
\text { Muharto Traditional Market }\end{array}$ \\
\hline Social interaction and stratification & $\begin{array}{l}\text { Green Space } \\
\text { Malang Regency } \\
\text { Praying houses in Malang }\end{array}$ \\
\hline Social change & $\begin{array}{l}\text { Kampung Jodipan } \\
\text { Kampung Tridi } \\
\text { Malang }\end{array}$ \\
\hline Local and global culture & $\begin{array}{l}\text { Surakarta Palace } \\
\text { Radya Pustaka Museum } \\
\text { Keris Museum } \\
\text { Batik Danarhadi Museum } \\
\text { Balekambang Garden }\end{array}$ \\
\hline Gaps, stratification and mobility & $\begin{array}{l}\text { Batu Municipaliy } \\
\text { Omah Kayu in pine forest } \\
\text { Pasar Terapung }\end{array}$ \\
\hline
\end{tabular}

\section{Result and Discussion}

One of the strengths of MOOC, in this learning innovation, is that video is contextual rather than monotonous and boring content. Video with good images based on contextual and real examples, clear sound with subtitles explaining it and coupled with structured material with evaluations that are also structured, will please the audience to stay focused and stay tuned in MOOC. If this is forgotten by the creator of the MOOC, then it is not impossible, this MOOC will not last long. So that a serious effort is needed in making the MOOC in order to provide the best both in terms of visuals, materials, and also the sound produced. 


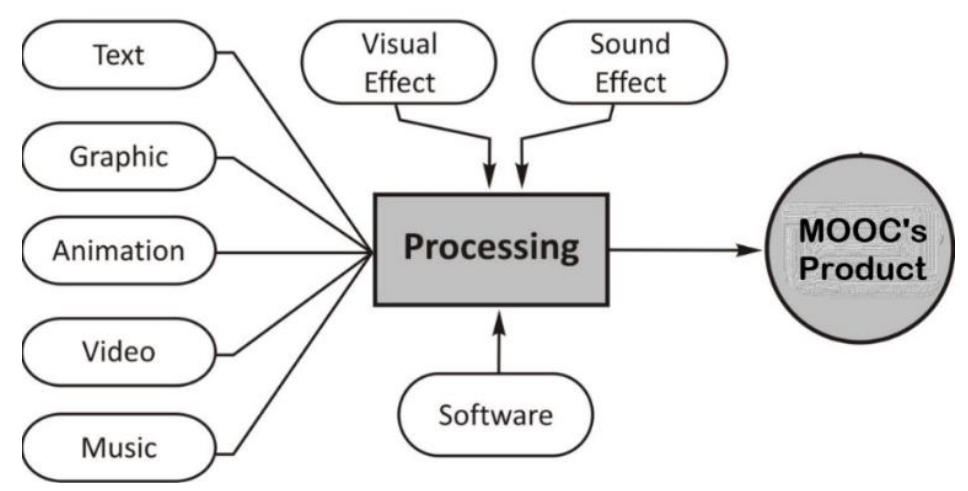

Fig. 2. The steps of producing contextual-based video in MOOC

This development consists of two parts including a focus on content, such as text, context and music, and a focus on graphics, animation and video.

\subsection{Contextual learning}

The next test was carried out during the lecture process which not only involved the introduction to Sociology students but also the learning innovation development team so that two heads are better than one would be achieved.

Table 2. Learning activities

\begin{tabular}{|c|l|l|}
\hline No. & \multicolumn{1}{|c|}{ Indicators } & \multicolumn{1}{c|}{ Information } \\
\hline 1 & Learning objectives & $\begin{array}{l}\text { Learning objectives provide experience as well as student knowledge } \\
\text { and skills }\end{array}$ \\
\hline 2 & Lecture activities process & $\begin{array}{l}\text { Students are active and really like the lecture process, this is shown } \\
\text { with high enthusiasm and even tend to ask for more time. }\end{array}$ \\
\hline 3 & Contextual video & $\begin{array}{l}\text { Content and context are quite relevant, only a few voices are still dif- } \\
\text { ferent and writing errors are very small in number }\end{array}$ \\
\hline 4 & Module & $\begin{array}{l}\text { Provide sufficient knowledge and information, including a clear level } \\
\text { of readability because each chapter is neither too thick nor too thin. }\end{array}$ \\
\hline
\end{tabular}

This development is aimed at learning about the origins of sociology as a discipline and is introduced to the main sociological theories and research methods. When following throughout the course, the imagination of sociology will be built by connecting relevant topics and theories. Expected Learning Outcomes are:

1) Understanding the key concepts in sociology especially those related to individuals and society

2) Developing understanding in sociological imagination between evidence or data with sociological arguments

3) Understanding approaches and methods in sociological research such as design, methods, and ethics

4) Identifying social problems professionally. 


\subsection{Implementation}

The product was implemented in front of class 2018 students, both class A or offering B, Sociology Education study program, State University of Malang. They were asked to watch and watch videos with material "Understanding Sociology" and "Social Interaction and Structure". In the initial stage, students watched through LCD shows not through www.mooc.um.ac.id because at the initial testing stage, the web provided was not fully able to run well and was still in the maintenance stage. The result of product implementation can be seen in the following figure.

\begin{tabular}{|l|l|}
\hline $\begin{array}{l}\text { Memahami Sosiologi } \\
\text { Played on }\end{array}$ & 15 Oct 2018 \\
\hline Hosted by & luhungachmad \\
\hline Played with & 35 players \\
\hline Played & 10 of 10 questions \\
\hline & \\
\hline Overall Performance & \\
\hline Total correct answers (\%) & $61.65 \%$ \\
\hline Total incorrect answers (\%) & $38.35 \%$ \\
\hline Average score (points) & 5650.43 points \\
\hline
\end{tabular}

Fig. 3. The average value of product implementation

During watching videos through the LCD, students are asked to focus on the substance of the material and see the context presented in the video. After that, train the level of understanding and concentration of students to work on the test with a synchronous online model using the www.kahoot.it website that has been prepared by the lecturer. The students were asked to issue their own devices to enter the PIN number as a prerequisite for participating in this kahoot game. The game, then, starts and results in a relatively high level of student understanding with relatively good results with an average score reaching 65 . In fact, the students only watch in one run. It is assumed that if they watch more, the results can be much better.

Students, after the game is over, are asked their opinions online about the learning that has been carried out whether they like it or not. The result was that almost all participants preferred the learning activities process. Even more exciting, all participants wanted to recommend this activity to their colleagues. Thus, students really enjoy new learning activities, fun, and interesting. The level of student's satisfaction is as follow:

\begin{tabular}{|c|c|c|c|c|c|c|}
\hline \multicolumn{7}{|l|}{ Feedback } \\
\hline How fun was it? (out of 5 ) & \multicolumn{6}{|c|}{5.00 out of 5} \\
\hline Did you learn something? & \multicolumn{2}{|c|}{$88.75 \%$ Yes } & \multicolumn{2}{|c|}{$11.25 \%$ No } & & \\
\hline Do you recommend it? & \multicolumn{2}{|c|}{$100.00 \%$ Yes } & \multicolumn{2}{|c|}{$0.00 \%$ № } & & \\
\hline How do you feel? & 0 & $100.00 \%$ Positive & 0 & $0.00 \%$ Neutral & 0 & $0.00 \%$ Negative \\
\hline
\end{tabular}

Fig. 4. The level of student's satisfaction 


\subsection{Revision}

Some of the revisions made in this development, based on user input, are improving video content, both the storyline, typo transcripts, and the suitability of the text with the relevant context. The video was revised internally and did not involve outside parties.

Students really like the development of contemporary innovations. This means, based on the results of observations in class, the average student a minimum of playing a mobile phone for at least 3 hours. Thus, the approach and development of learning should be directed towards millennial development rather than traditional conventional lectures while still being student centered. Introduction to Sociology must provide sufficient space for students to build their sociological imagination.

\section{Conclusion}

The learning method has significantly undergone many fundamental changes. Conventional learning cannot be maintained where students generally demand to experience fun and practical learning activities. MOOC is an alternative solution by providing enormous opportunities through digital platforms that anyone and anywhere can access easily. Contextual video that becomes teaching material in the learning process should also be a concern that can create a relationship between educators and learners with no space limit. Through the development of interactive video content and MOOC-based learning, it provides vast opportunities to anyone and anywhere for those who want to learn sociology with free and easy access [16].

\section{$5 \quad$ References}

[1] I. U. Khan, Z. Hameed, Y. Yu, T. Islam, Z. Sheikh, and S. U. Khan, "Predicting the acceptance of MOOCs in a developing country: Application of task-technology fit model, social motivation, and self-determination theory,” Telemat. Inform., vol. 35, no. 4, pp. 964978, Jul. 2018. https://doi.org/10.1016/j.tele.2017.09.009.

[2] B. Kurniawan, I. Idris, A. Purnomo, A. Wiradimadja, and S. Sukamto, "Using Broadcasting Learning Design to Enhance Student's Experiential Skill," Int. J. Emerg. Technol. Learn. IJET, vol. 14, no. 16, pp. 172-180, Aug. 2019. https://doi.org/10.3991/ijet.v14i16.10652.

[3] K. H. Lau, T. Lam, B. H. Kam, M. Nkhoma, J. Richardson, and S. Thomas, "The role of textbook learning resources in e-learning: A taxonomic study," Comput. Educ., vol. 118, pp. 10-24, Mar. 2018. https://doi.org/10.1016/j.compedu.2017.11.005.

[4] W. D. Sulistyo, U. Nafi'ah, and I. Idris, "The Development of E-PAS Based on Massive Open Online Courses (MOOC) on Local History Materials,” Int. J. Emerg. Technol. Learn. IJET, vol. 14, no. 09, p. 119, May 2019. https://doi.org/10.3991/ijet.v14i09.10143.

[5] K.-S. Hong, A. A. Ridzuan, and M.-K. Kuek, "Students' attitudes toward the use of the Internet for learning: A study at a university in Malaysia," J. Educ. Technol. Soc., vol. 6, no. 2, pp. 45-49, 2019.

[6] D. Gibson, T. Broadley, J. Downie, and P. Wallet, "Evolving Learning Paradigms: Re-Setting Baselines and Collection Methods of Information and Communication Technology in Education Statistics," Educ. Technol. Soc., vol. 21, no. 2, pp. 62-73, 2018.

[7] D. Lupton, Digital sociology. UK: Routledge, 2014. 
[8] K. P. Polanyi, The great transformation:(The political and economic origin of our time). US.: Beacon Press, 1957.

[9] Y. Jung and J. Lee, "Learning Engagement and Persistence in Massive Open Online Courses (MOOCS)," Comput. Educ., vol. 122, pp. 9-22, Jul. 2018. https://doi.org/10. 1016/j.compedu.2018.02.013.

[10] Y. J. Joo, S. Park, and E. Lim, "Factors Influencing Preservice Teachers' Intention to Use Technology," Educ. Technol. Soc., vol. 21, no. 3, pp. 48-59, 2018.

[11] T. Zhu, "Empirical Research on the Effectiveness of MOOCs in Developing Design Students on Sino-foreign Cooperation University Programs," Int. J. Emerg. Technol. Learn. IJET, vol. 11, no. 06, p. 19, Jun. 2016. https://doi.org/10.3991/ijet.v11i06.5304.

[12] Z. Ji, “Application and Empirical Investigation of New MOOC Teaching System in Computer Application Course," Int. J. Emerg. Technol. Learn. IJET, vol. 11, no. 05, p. 62, May 2016. https://doi.org/10.3991/ijet.v11i05.5696.

[13] Y. Zhang, J. Chen, D. Miao, and C. Zhang, "Design and Analysis of an Interactive MOOC Teaching System Based on Virtual Reality," Int. J. Emerg. Technol. Learn. IJET, vol. 13, no. 07, p. 111, Jun. 2018. https://doi.org/10.3991/ijet.v13i07.8790.

[14] M. B. Hoy, "MOOCs 101: An Introduction to Massive Open Online Courses," Med. Ref. Serv. Q., vol. 33, no. 1, pp. 85-91, 2014, doi: DOI: 10.1080/02763869.2014.866490.

[15] J. Daniel, "Making Sense of MOOCs: Musings in a Maze of Myth, Paradox and Possibility," J. Interact. Media Educ., vol. 3, p. 18, 2012. https://doi.org/10.5334/2012-18.

[16] E. Costello, J. Brunton, M. Brown, and L. Daly, "In MOOCs we Trust: Learner Perceptions of MOOC Quality via Trust and Credibility,” Int. J. Emerg. Technol. Learn. IJET, vol. 13, no. 06, p. 214, May 2018. https://doi.org/10.3991/ijet.v13i06.8447

\section{Authors}

Luhung Achmad Perguna, is member of lecturer in Department of Sociology, Faculty of Social Sciences, Universitas Negeri Malang. His main research interest is sociological studies and learning resources media.

Idris is one of the lecturers in Social Studies Program, Faculty of Social Science, Universitas Negeri Malang. He is interested in learning innovation.

Irawan is an Indonesian Sociological Education, one of the lecturers in Department of Sociology, Faculty of Social Science, Universitas Negeri Malang. He is interested in educational sociology and learning media.

Article submitted 2020-01-30. Resubmitted 2020-03-01. Final acceptance 2020-03-01. Final version published as submitted by the authors. 